THE KURUME MEDICAL JOURNAL

Vol. 40, p. $93-99,1993$

\title{
Mast Cells and Histamine Release in Crohn's Disease
}

\author{
YASUMI ARAKI, TERUO KAKEGAWA AND *FLEMMING STADIL \\ Department of Surgery, Kurume University School of Medicine, Kurume, 830 Japan \\ and *Department of Gastrointestinal Surgery, Rigshospitalet, Copenhagen, Denmark
}

Received for publication April 26, 1993

\begin{abstract}
Summary: To study the role of intestinal mast cells in Crohn's disease, a sensitive glass-fiber histamine assay was conducted in conjunction with mechanical dispersion of surgical specimens of 80 macroscopically actively inflamed colons, 40 non-inflamed colons, 40 actively inflamed ileums, and 16 non-inflamed ileums from patients with Crohn's disease and 96 control subjects. A strong correlation was found between the number of mast cells and the total histamine content in the controls $(r=0.682)(p<0.05)$. The number of mast cells was decreased in Crohn's disease as compared with the controls $(p<0.01)$. Intestinal mast cells release histamine in a dose-dependent manner after challenges with anti-IgE $(1.875-240.0 \mathrm{U} / \mathrm{ml})$. A significant difference was noted in the release by anti-IgE between actively inflamed and non-inflamed colons of patients with Crohn's disease or control subjects ( $p<$ 0.01). Mast cells in actively inflamed tissue with Crohn's disease were shown to have different roles in the pathogenesis of inflammation.
\end{abstract}

Key words: Crohn's disease - histamine release - anti-IgE - intestinal mast cell - a sensitive glass fiber histamine assay

\section{Introduction}

Schwartz et al. (1983) and Spiegelberg (1984) reported intestinal mast cells degranulate in response to the complementderived anaphylatoxins $\mathrm{C} 3 \mathrm{a}, \mathrm{C} 4 \mathrm{a}$, and $\mathrm{C} 5 \mathrm{a}$, and to cytokines from lymphocytes and monocytes. Following the binding of a specific antigen to surface-bound $\operatorname{IgE}$, mast cells in the intestinal tract may contribute to, and/or reflect the intensity of the inflammatory process. Thus these cells may be initiators of acute inflammation and propagate chronic change. However, the functional role of intestinal mast cells in Crohn's disease has not been established, because of the removal of $\mathrm{IgE}$ from a low-affinity receptor during the cell isolation procedure. Recently, a sensitive and specific glass-fiber assay of histamine was developed (Nolte et al. 1989) which measures histamine fluorometrically from dispersed intestinal mast cells using small biopsy specimens. This assay was used to examine the histamine released by anti-IgE from mechanically dispersed mast cells of surgical specimens in Crohn's disease.

\section{Materials and Methods}

\section{Patients}

Surgical specimens from 80 macroscopically actively inflamed colons, 40 noninflamed colons, 40 actively inflamed il-

Correspondence and reprint requests to: Yasumi Araki, M.D., The First Department of Surgery, Kurume University School of Medicine, 67 Asahi-machi, Kurume, 830 Japan. 
eums, and 16 non-inflamed ileums from patients with Crohn's disese who underwent emergent bowel resection at Rigshospitalet (Copenhagen) were studied. The diagnosis of Crohn's disease was based on standard clinical, radiographic and pathological criteria (Morson, 1972; Janowitz and Sachar, 1976). Control subjects (96) were patients undergoing bowel resections for carcinomas and diverticula.

\section{Reagents}

For the histamine release experiments, Pipes-AMC buffer (pH 7.4) and anti-IgE $(2400 \mathrm{U} / \mathrm{ml})$ obtained from SIGMA were used, and the histamine releasing agents were diluted in Pipes-AMC buffer.

\section{Morphometry}

Tissue sections were immediately fixed in $4 \%$ neutral buffered formalin, and parafin sections $(5 \mu \mathrm{m}$ thick) were stained by the standard method with toludine blue ( $\mathrm{pH} \mathrm{4.0)} \mathrm{(Fig.} \mathrm{1)} \mathrm{to} \mathrm{localize} \mathrm{the} \mathrm{mast}$ cells by light microscopy (Enerbac, 1962; Strobel et al. 1981). Field analysis was conducted by counting mast cells under a Leitz microscope (eyepiece $\times 10$, objective $\times 40$ ). A $10 \mathrm{~mm}^{2}$ eye piece graticule, calibrated with a calibration slide, was used. The edge of the graticule was orientated below the base of the muscularis mucosa. On each slide, nine fields (290 $\mu \mathrm{m} \times 290 \mu \mathrm{m}$; area $0.084 \mathrm{~mm}^{2}$ ) were counted (Brandtzaeg et al. 1974; Selbekk et al. 1980) and all measurements were repeated with an observer variation of less than $5 \%$. The mast cell density was expressed as the number of cells per $\mathrm{mm}^{2}$.

\section{Histamine content and histamine release}

Tissue sections were immediately transferred to $5 \mathrm{ml}$ Pipes-AMC (final concentration of $10 \%$ human serum al-

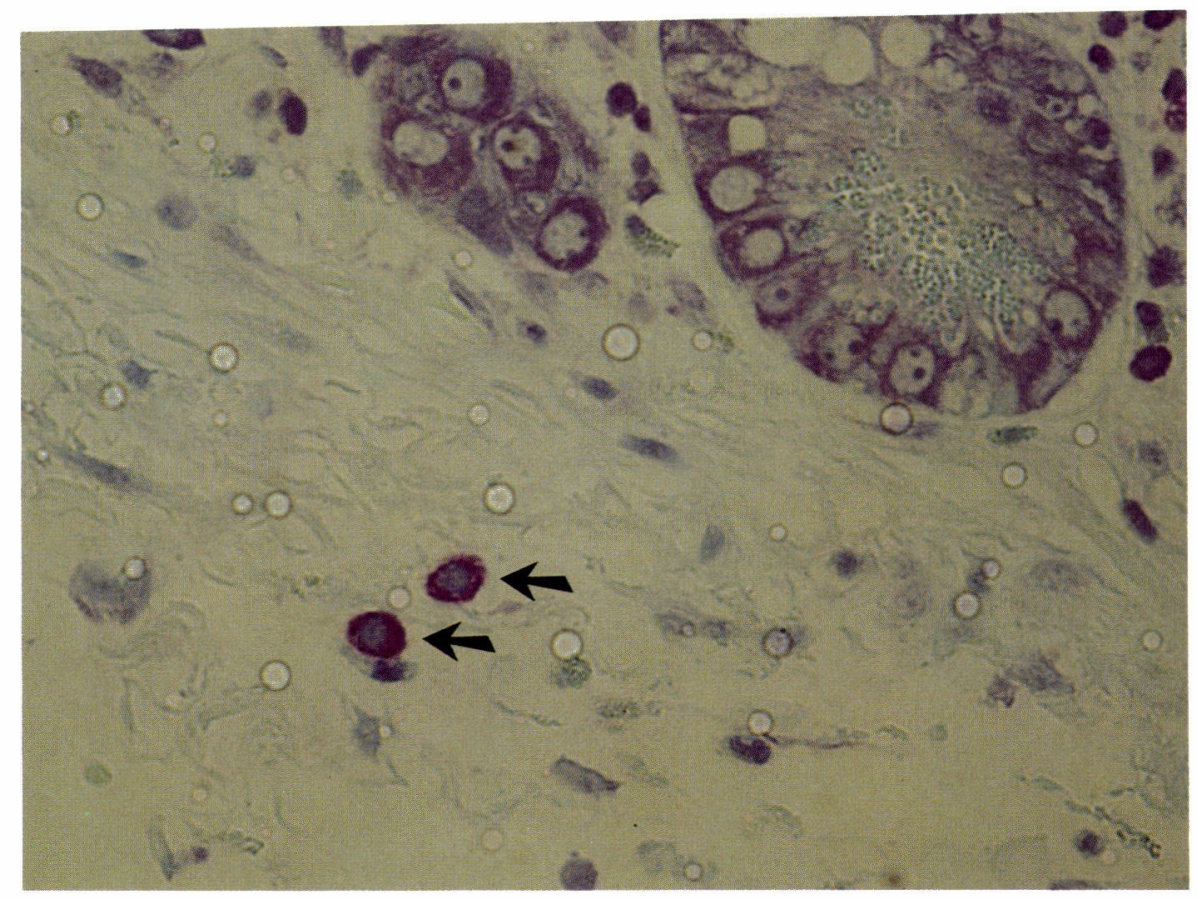

Fig. 1. Mast cells indicated by the black arrows (仓) were stained by the standard method with toludine blue ( $\mathrm{pH} \mathrm{4.0)}$. 
bumin) at $4{ }^{\circ} \mathrm{C}$ within two hours and chopped to a size of $0.5 \mathrm{~mm}$ with a scissors following removal of the propria muscle and elastic tissue. Each of the specimens was separated into 8 groups and wet weighed. All specimens were resuspended in $(1.0 \mathrm{ml})$ Pipes-AMC for $30 \mathrm{~min}$ at $37^{\circ} \mathrm{C}$. After centrifugation (2 $\mathrm{min}$ at room temperature at $2,000 \mathrm{~g}$ ) the supernatant was removed for histamine analysis. The histamine was released spontaneously. Samples were incubated for $60 \mathrm{~min}$ at $37^{\circ} \mathrm{C}$ at the following final dilutions: anti-IgE $1.875 \mathrm{U} / \mathrm{ml}(\times 1280)$, $3.750 \mathrm{U} / \mathrm{ml}(\times 640), \quad 7.50 \mathrm{U} / \mathrm{ml}(\times 320)$, $15.0 \mathrm{U} / \mathrm{ml}(\times 160), 30.0 \mathrm{U} / \mathrm{ml}(\times 80), 60.0$ $\mathrm{U} / \mathrm{ml}(\times 40), 120.0 \mathrm{U} / \mathrm{ml}(\times 20)$ and 240.0 $\mathrm{U} / \mathrm{ml}(\times 10)$. Each supernatant was subjected to histamine analysis. The histamine was released by a challenge. Samples were resuspended in $2 \mathrm{ml}$ Pipes-AMC and placed in a boiling water bath for $10 \mathrm{~min}$ to release any remaining histamine. Following centrifugation $(2,500 \mathrm{~g}$ for $5 \mathrm{~min}$ ) the supernatant was used for the histamine assay. The histamine released by this procedure was the residual histamine.

Histamine concentrations were measured by the fluorometric $\mathrm{O}$-pthaldialdehyde method using a Perkin-Elmer LS 2 spectrophotofluorometer with a microtiterplate autosampler reported by Skov et al. (1984) and Nolte et al (1990). The glass microfiber-based histamine assay was conducted by Reference Laboratory (Copenhagen). Total histamine content was calculated as the sum of the spontaneous release, the release following challenge and the residual histamine. The content was expressed as ng histamine / $\mathrm{mg}$ wet weight of tissue.

The percentage of spontaneous release was calculated as follows:

$\frac{\text { histamine released spontaneously }}{\text { total histamine }} \times 100$

The percentage of released histamine after anti-IgE was determined as:

$\frac{\text { histamine released after challenge }}{\text { total histamine }} \times 100$

Significance was assessed by the Student's $t$ test, regression analysis, and Mann-Whitney test. Differences below $p=0.05$ were considered significant.

\section{Results}

\section{Number of mast cells}

The numbers of intestinal mast cells from three different areas of the bowel were determined in tissues from control, non-inflamed ileum, actively inflamed ileum, non-inflamed colon, and actively inflamed colon in patients with Crohn's disease (Table 1). As compared to the control group, a highly significant de-

TABLE 1.

Number of intestinal mast cells $/ \mathrm{mm}^{2}$

\begin{tabular}{lcccc}
\hline & $\begin{array}{c}\text { non-inflamed } \\
\text { ileum }\end{array}$ & $\begin{array}{c}\text { inflamed } \\
\text { ileum }\end{array}$ & $\begin{array}{c}\text { non-inflamed } \\
\text { colon }\end{array}$ & $\begin{array}{c}\text { inflamed } \\
\text { colon }\end{array}$ \\
\hline Control Patients & - & - & $122.9(25.7)$ & - \\
Crohn's disease & $75.0(21.2)^{*}$ & $62.9(8.6)^{*}$ & $54.3(21.0)^{*}$ & $65.6(16.0)^{*}$ \\
\hline
\end{tabular}

The data are expressed as the mean \pm standard deviation.

$* \mathrm{p}<0.01$ indicates a significant difference from control. 
crease was noted in the number of mast cells per $\mathrm{mm}^{2}$ in patients with Crohn's disease $(\mathrm{p}<0.01)$.

\section{Total histamine content}

There was a strong correlation between the number of mast cells and the total histamine content in the control group $(\mathrm{r}=0.682)$ (Fig. 2). Assuming a tissue density of $1 \mathrm{mg} / \mathrm{mm}^{3}$, the histamine con-

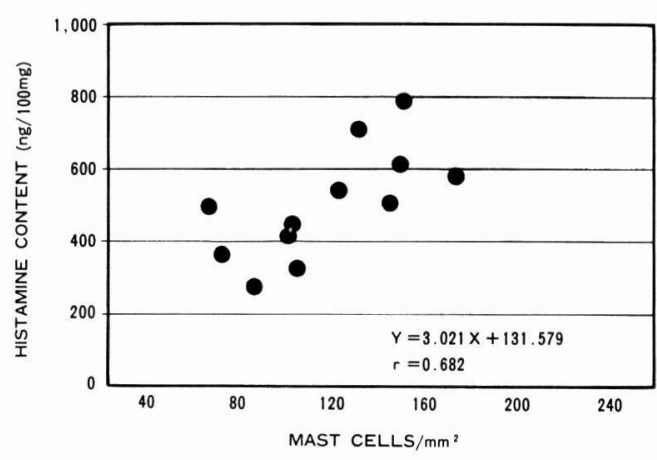

Fig. 2. Correlation between total histamine content and number of intestinal mast cells in control tissues from surgical specimens $(r=0.682)(p<0.05)$.

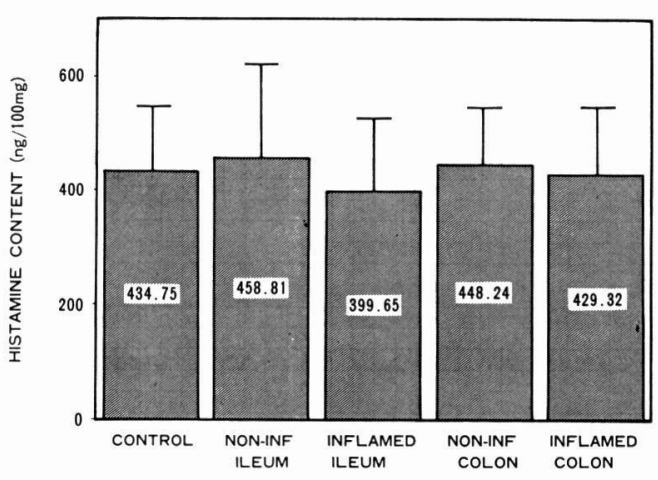

Fig. 3. Total histamine content (ng/100 $\mathrm{mg}$ ) of specimens from the colons in control subjects $(n=96)$ and from non-inflamed ileums $(n=16)$, actively inflamed ileums $(n=40)$, non-inflamed colons $(n=40)$, and actively inflamed colons $(n=80)$ in patients with Crohn's disease (N.C.). tent was found to be $44.8 \mathrm{pg} / \mathrm{cell}$. No significant difference in total histamine content of actively inflamed tissue and either non-inflamed tissue with Crohn's disease or control tissue could be found (Fig. 3).

\section{Spontaneous histamine release rates}

Fig. 4 shows that mast cells from control patients and patients with Crohn's disease had less spontaneous histamine release from the colon than from the terminal ileum. No significant difference in spontaneous histamine release from the colon in Crohn's disease and control tissues was found.

\section{Histamine release rates after challenges with ant $i-\operatorname{Ig} E$}

Intestinal mast cells from control tissues released histamine in a dose-dependent manner after challenges with anti-IgE $(1.875-240.0 \mathrm{U} / \mathrm{ml})$. A significant difference in the rate of histamine release after challenge with anti-IgE was found between the actively inflamed colon and the non-inflamed colon in Crohn's disease

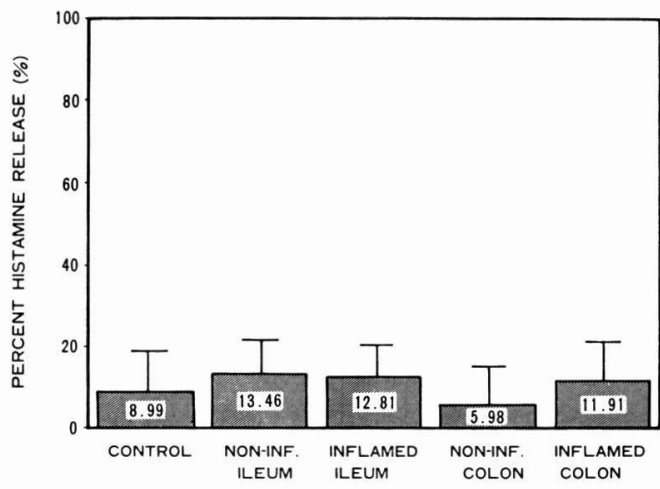

Fig. 4. Spontaneous histamine release rates $(\%)$ from specimens of control subjects $(n=96)$, and from specimens of noninflamed ileums $(n=40)$, actively inflamed ileums $(n=16)$, non-inflamed colons $(n=40)$ and actively inflamed colons $(n=80)$ of patients with Crohn's disease (N.C.). 


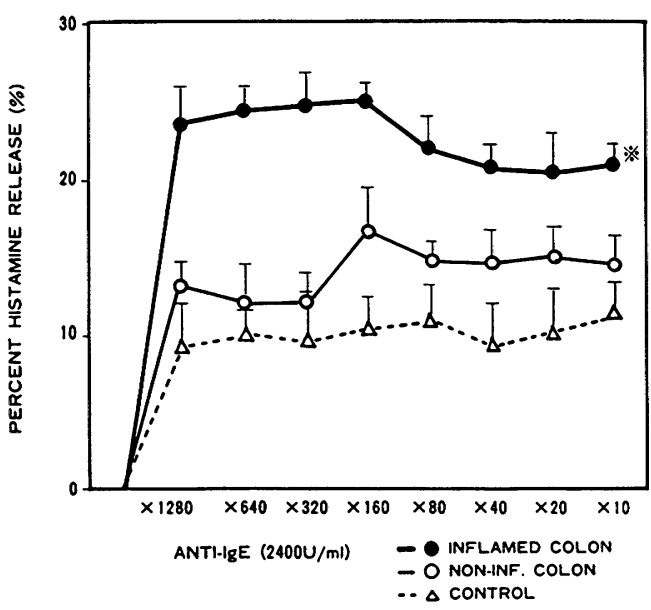

Fig. 5. Histamine release rates (\%) after challenges with anti-IgE from specimens of control subjects $(\Delta)(n=12)$, and non-inflamed colon $(0)(\mathrm{n}=10)$, and actively inflamed colon $(\bullet)(n=10)$ with Crohn's disease. The data are expressed as the mean \pm standard deviation. $* \mathrm{P}<0.01$ indicates a significant difference from the non-inflamed colon and control subjects.

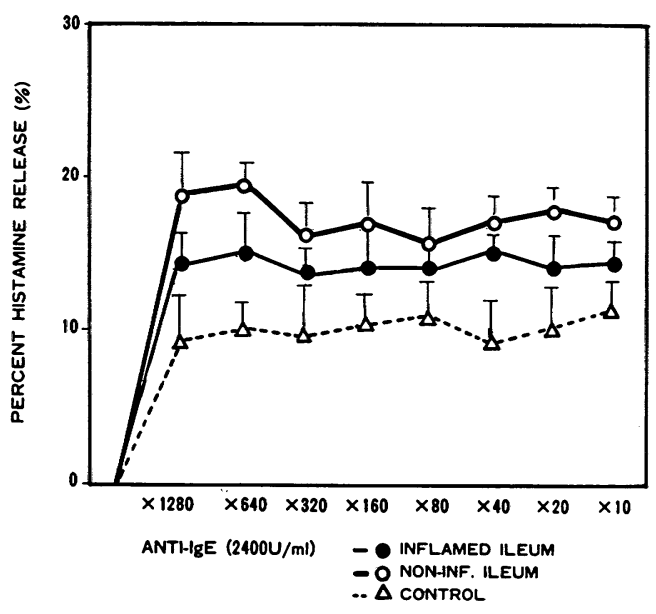

Fig. 6. Histamine release rates (\%) after challenges with anti-IgE from control specimens $(\Delta)(n=12)$, and non-inflamed ileum $(0)(n=11)$, or actively inflamed ileum $(\bullet)(n=11)$ with Crohn's disease (N.C.). The data are expressed as the mean \pm standard deviation. or control tissues $(\mathrm{p}<0.01)$ (Fig. 5). Otherwise, no significant differences in the rates of histamine release after challenges with anti-IgE from actively inflamed ileum, non-inflamed ileum in Crohn's disease and control tissues were found (Fig. 6).

\section{Discussion}

The early lesions of Crohn's disease, the study of which should provide insight into how the disease is initiated, have been examined by observing seemingly uninvolved areas of bowel wall adjacent to areas with frank disease. Mast cells increase modestly in Crohn's disease, particularly in the submucosal area and around blood vessels (Dvorac et al. 1978). However, mast cells may be increased (Hiatt et al. 1962), remain unchanged (Thompson et al. 1979), or be decreased (Lloyd et al. 1975; Sanderson et al. 1986) in Crohn's disease. In this study, analysis of histological sections demonstrated that there is a significant decrease of intestinal mast cells in actively inflamed tissue with Crohn's disease. The reason for this discrepancy from previous reports may be due to difficulties in preserving mast cell structure during fixation of tissues. Electron microscopic studies (Dvorac and Monahan, 1983) have indicated that mast cells in the active areas of Crohn's disease are degranulated, which may contribute to an understanding of the mast cell density. These cells undoubtedly facilitate the influx of additional cellular elements into an already established lesion. Capron et al. (1986) have reported the stimulus for mediator release was goat anti-IgE, which induces release by cross-linking IgE molecules that are bound to the high-affinity $\operatorname{IgE}$ receptors on the mast cell. Eosinophils, lymphocytes, and monocytes are known to have low-affinity receptors for $\mathrm{IgE}$, but the conditions of 
the cell isolation procedure with drugs and multiple washes should remove IgE from the low-affinity receptor.

Recently, glass-microfibers have been found to bind histamine with high affinity and selectivity, and this method was used to study the histamine release by anti-IgE from mast cells obtained from surgical specimens in Crohn's disease that were dispersed mechanically (Skov et al. 1985). The activation may be unique to Crohn's disease. In fact, mast cells would respond in an inflammatory role with the type of activation or hyperresponsiveness observed. Histamine releasing activity appears to be produced by $\mathrm{T}$ lymphocytes and this production is stimulated by antigens and $\mathrm{T}$ cell mitogens (Nable et al. 1981; Sedgwick et al. 1981; Shulman et al. 1985). Intestinal mast cells need $T$ cell factors (IL-3, IL-4) for maturation, but there also seems to be a more direct relationship between these cells in the induction of mediator release. It is especially interesting that the differences in mast cell responsiveness are seen after challenges with low doses of $\operatorname{IgE}$ in spite of in significant differences in the spontaneous release of histamine between inflamed tissues and either non-inflamed tissues with Crohn's disease or control tissues. This indicates that a lymphokine or other cytokine induces a substantial change in the signal transduction apparatus. The increased levels of histamine could be explained by changes in the cytoskeleton that allow greater exocytosis of granules or changes in the granules themselves, further allowing greater liberation of histamine from the proteoglycan matrix. However, that would not account for the increased levels of newly generated mediators, such as the arachidonic acid metabolites. The increase is perhaps better explained by a modulation of the signal transduction pathway, such as increased levels of the enzymes involved in cell activation (protein kinases, phos- pholipases, etc.), or by an increase in the levels of precursors. Conversely, there is also the possibility that the hyperresponsiveness seen in the active areas is caused by removal of suppression rather than an activation, and that a factor that usually down-regulates the mast cells is not present.

This study indicates that intestinal mast cells from actively inflamed tissue with Crohn's disease may degranulate easily and release histamine and/or inflamed tissue has high levels of $\mathrm{T}$ cell factors (IL-3, IL-4) for maturation of mast cells. Mast cells may thus play a functional role in Crohn's disease.

Acknowledgments: We thank Dr. H. Esther and Dr. M. Anne for staining sections for light microscopy and examing specimens under the electron microscope.

\section{References}

Brandtzaeg, P., Baklien, K., Fausa, O. and Hoel, P.S. (1974). Immunohistochemical characterization of local immunoglobulin formation in ulcerative colitis. Gastroenterogy 66, 11231136.

Capron, A., Dessaint, J.P., Capron, M., Joserh, M., Ameisen, J.C. et al. (1986). From parasites to allergy: a second receptor for IgE. Immunol. Today 7, 15-18.

Dvorac, A.M. and Monahan, R.A. (1983). Crohn's disease-mast cells quantitation using one micron plastic sections for light microscopy. Pathol. Annu. 18, 181-190.

Dvorac, A.M., Monahan, R. A., Osage, J.E. and Dickersin, G.R. (1978). Mast-cell degranulation in Crohn's disease. Lancet 1, 498.

EnARbac, K.L. (1962). Mast cells in rat gastrointestinal mucosa. Acta Path. Microbiol. Scand. 66, 303-312.

Hiatt, R.B. and Katz, L. (1962). Mast cells in inflammatory conditions of the gastrointestinal tract. Am. J. Gastroenterol. 37, 541545.

JANowitz, H.D. and SAChar, D.B. (1976). New observations in Crohn's disease. Ann. Rev. 
Med. 27, 269.

Lloyd, G., Green, F.H.Y., Fox, H., Mani, V. and Turnberg, L. A. (1975). Mast cells and immunoglobuline $\mathrm{E}$ in inflammatory bowel disease. Gut 16, 861-866.

Morson, B.C. (1972). Pathology of Crohn's disease. Clin. Gastroenteol. 1, 265.

Nable, G., Galli, S.J., Dvorack, A.M. and Dvorack, H.F. (1981). Inducer T lymphocytes synthesize a factor that stimulates proliferation of cloned mast cells. Nature 291, 332334.

Nolte, H., Skov, P.S., KruSe, A. and SchiфTz, P.O. (1989). Histamine release from dispersed human intestinal mast cells. Allergy 44, 543553.

Nolte, H., Spjeldnaes, N., Kruse, A. and WINDELBORG, B. (1990). Histamine release from gut mast cells from patients with inflammatory bowel diseases. Gut 31, 791-794.

Sanderson, I. R., Pleung, K.B., Pearce, F.L. and WALKER, J. A. (1986). Lamina propria mast cells in biopsies from children with Crohn's disease. J. Clin. Pathol. 39, 279-283.

Schwartz, L.B., Kawahara, M.S., Hugh, T.E., VIK, D., FEARON, D. T. et al. (1983). Generation of C3a anaphylatoxin from human C3 by human mast cell tryptase. J. Immunol. 130, 1891-1895.

Sedgwick, J.D., Holt, P.G. and Turner, K.J. (1981). Production of a histamine-releasing lymphokine by antigen -or mitogen- stimulated human peripheral $\mathrm{T}$ cells. Clin. Exp. Immunol. 45, 409-418.
Selbekk, B.H., Flaten, O. and Hanssen, L.E. (1980). The in vitro effect of neurotensin on human jejunal mast cells. Scand. J. Gastroent. 15, 457-460.

Shulman, E.S., Liu, M.C., Proud, D., Macglashan, D. W., Lichtenstein, L.M. et al. (1985). Human lung macrophages induce histamine release from basophils and mast cells. Am. Rev. Respir. Dis. 131, 230-235.

Skov, P.S., Mosbech, H., Norn, S. and Weeke, B. (1985). Sensitive glass microfiber based histamine analysis for allergy testing in washed blood cells. Allergy 40, 213-218.

Skov, P.S., Norn, S. and Weeke, B. (1984). A new method for detecting histamine release. Agents Actions 14, 414-416.

Spiegelberg, H.L. (1984). Structure and function of Fc receptors for IgE on lymphocytes, monocytes, and macrophages. Adv. Immunol. 35, 61-88.

Strobel, S., Miller, H.R. and Ferguson, A. (1981). Human intestinal mucosal mast cells : evaluation of fixation and staining techniques. J. Clin. Pathol. 34, 851-858.

Thompson, H. and Buchmann, P. (1979). Mast cell population in rectal biopsies from patients with Crohn's disease. In Crohn's dis. ease, ed. Thompson, H. and Buchmann, P., pp. 697-701. London: Pitman Press.

Thueson, D. O., Speck, L.S., Lett-Brown, M. A. and Grant, J. A. (1979). Histamine-releasing activity (HRA); I. Production by mitogenor antigen-stimulated human mononuclear cells. J. Immunol. 123, 626-632. 